\title{
Uncontrolled Drilling: Exposing a Global Threat to Groundwater Sustainability
}

\author{
Romain Chesnaux \\ Department of Applied Sciences, Université du Québec à Chicoutimi, Chicoutimi, Canada \\ Email: romain_chesnaux@uqac.ca
}

Received June 9, 2012; revised July 12, 2012; accepted August 24, 2012

\begin{abstract}
Untold numbers of boreholes are drilled into the earth's crust every year. Most constitute a potential threat to groundwater quality by creating a preferred pathway for contaminant migration. Some solutions, including “well-pooling”, are proposed to better protect groundwater resources through the efficient management of boreholes.
\end{abstract}

Keywords: Groundwater Resources; Contamination; Drilling; Well-Pooling

I recently attended GeoHydro2011 in Quebec City, Canada, a conference on groundwater resources. I spent some time asking my hydrogeologist colleagues a few simple questions: In your estimation, how many wells have been drilled in the world? No one knows. In Canada? No one knows. If one wanted to determine the number of wells drilled in Canada (including for geotechnical, oil and gas, water, etc. purposes), which government body or professional association should be consulted? None among my colleagues, all specialists in groundwater resource management, could provide an answer. Extensive research has led me to conclude that comprehensive regional or national listings of all boreholes do not exist.

Every day, hundreds, even thousands, of boreholes are drilled in the earth's crust. Drilling is occurring in all parts of the world: in the mountains, in the wilderness, in the far North, in cities, in suburbs, in the countryside, in the rainforest, in the deserts. Farmers and country residents are hiring private drilling contractors for their watersupply wells. Petroleum companies are drilling for oil and gas (sometimes kilometres deep). Exploration companies and mining conglomerates are drilling for minerals. Municipal governments are drilling to supply their populations with drinking water and monitor its quality. Universities are drilling for groundwater research. Engineering consulting firms are drilling for geotechnical projects. Construction companies are drilling to build bridges, roads and buildings. Most drilling is motivated by the exploitation of non-renewable (oil and gas) and renewable (groundwater, geothermal) resources.

Drilling can be considered as a wild (uncontrolled) activity. Little authority is exercised over the act of drilling, the quality of borehole seals or the management of wells on a local, municipal, provincial, national or global level. Today, it seems, holes can be drilled in the ground without anyone having to answer to the consequences.

Every time a borehole is drilled in the earth, a pathway of vulnerability is created with a potential for contamination and degradation of the groundwater resource [1-4]. Groundwater presents a contradictory situation: it is prized when it has been protected from human activity on the surface, but the very act of extracting it can contaminate the water or alter the underground environment that protects it. Approximately 2 billion people worldwide rely on aquifers for their drinking water supply [5].

Drilling into the subsurface can create hydraulic connections between contaminated surface water and the pristine underground water. These connections become preferential pathways for cross-contamination, which is the infiltration of surface contaminants into deeper (clean) aquifers [2,6-8]. When a borehole is drilled for purposes of drinking water extraction or monitoring, the usual practice consists of sealing the borehole to prevent surface contaminants from infiltrating through the annular space between the borehole wall and the casing [5]. Even though the practice of sealing a borehole is recommended or locally regulated to prevent cross-contamination, it is estimated that two-thirds of the wells worldwide may be improperly sealed [5]. Considering the lack of regulations on the quality of drilling methods and equipment, the risk of contamination of groundwater systems is likely to increase. Existing techniques for verifying and restoring borehole seal quality are extremely cost-intensive and rarely applied in practice [9-11]. When boreholes are drilled for purposes other than drinking water, such as in mineral or gas exploration, practices are 
even less regulated. Those boreholes are most often left open and not properly filled. A large number of abandoned or orphan wells likely exist that have not been filled or properly decommissioned [12]. These boreholes are future contaminant leaks waiting to happen [5].

Rarely is permission required or sought before a borehole is drilled. Many boreholes are drilled with no foreknowledge of the local conditions or the vulnerability of the underlying aquifers. The qualifications of the people and the quality of the practices, techniques and equipment used for drilling boreholes are not sufficiently regulated or controlled. Once a borehole is drilled, few laws and regulations serve to register its location and control its quality, integrity, use, lifespan and adequate decommissioning once it is no longer of use.

The unfortunate event that occurred in 2000 in the county of Walkerton in Ontario, Canada sadly illustrates the consequences of cross-contamination between surface water and groundwater in the vicinity of pumping wells used for a municipal water supply $[13,14]$. These contaminations had severe consequences on human health; cases of deaths were reported due to the infiltration of E. coli bacteria into the city's drinking water.

The vulnerability of aquifers can be measured and mapped on a regional level using well-known tools. The most widely used groundwater vulnerability mapping method is known as DRASTIC [15], which uses hydrogeological factors to identify areas where groundwater is most vulnerable and where there is greatest potential for groundwater contamination. The DRASTIC method, however, does not take into account the existence of boreholes. This is a significant weakness, since boreholes constitute a major contributor to the vulnerability of aquifers.

What will be the impact of uncontrolled drilling on groundwater, especially in areas where the density of boreholes is high? Nothing less than the endangerment of the availability, quantity, quality, and sustainability of drinking water supply for everyone, as well as the increasing cost of clean water, in the face of rising demand and need for the resource. New human settlements spreading to previously uninhabited areas may find that their potential reserves of groundwater have already been jeopardized by exploratory drilling. Exploratory drilling is increasing in areas that are being developed, especially in newly accessible Arctic zones where the ice pack is withdrawing due to climate change. Paradoxically, these areas will later be the site of human settlements with their requisite need for drinking water. Pristine aquifers may be already irrevocably contaminated by the time new settlers arrive.

In all these situations, the lack of political will, laws, regulations, control methods and database management that are exercised when boreholes are drilled will have both immediate and long-lasting repercussions on the quality, accessibility and sustainability of groundwater. Protecting the subsurface water resource and ensuring its sustainability should be a major political and environmental objective, and will require a concerted effort on many fronts. Experience has shown that the occurrence of borehole leakage decreases when regulations for well construction, operation and monitoring are improved [12]. The following recommendations represent an outline of measures which could be undertaken, some of which are urgent.

1. Raise awareness of the groundwater resource

a) Educate the public.

b) Train engineers, technicians and other professionals to be more aware of environmental risks arising from incorrectly drilled boreholes and improper seals.

c) Legislate the requirement for all municipal, local, and regional public governments to maintain a subsurface water management program.

2. Limit the number of boreholes drilled into the earth. Governments should better control the drilling activities that are occurring on their territories.

3. Institute and enforce regulations at a national, regional and municipal level for drilling, completion and abandonment of wells, regardless of their purpose.

a) Permission should be required and obtained from a relevant authority before drilling any hole in the ground, even on private property.

b) Reporting the existence of all boreholes and sharing the data must be required and enforced by law.

c) All boreholes should be georeferenced in a groundwater database.

d) Personnel involved in borehole drilling should have proper training and certification. Private drilling contractors should be certified and should be required to properly document their work.

e) New regulations and policies, as well as best management practices, should be implemented whereby all boreholes drilled for the purpose of water extraction must be protected by a wellhead protection area (e.g. no cattle grazing around wells, no human activity with potential for waste contamination, etc.).

f) The data provided by all contributors to a borehole database should be controlled for quality by a competent authority.

g) Orphan wells and boreholes that have been abandoned or are no longer active must be properly filled, protected and documented.

4. Well-pooling and community involvement: Carpooling owes its success to the fact that it not only helps the environment, it also helps individuals save money. Well-pooling can do the same. Everyone needs water, but not everyone needs to have a well on their property. 
Municipalities could incite residents to share existing wells or create partnerships in new wells. Communities also need to share in the responsibility for preserving their underground water resource, possibly by managing their regional borehole geodatabase.

5. Compile, map and maintain databases that record the groundwater resource and all regional boreholes [16]. These data can then be used to locate and measure different levels of vulnerability. Groundwater flow and transport numerical models, when properly calibrated and validated, can be used as a tool for predicting the impact of residential, agricultural and industrial development on groundwater. Databases can be used as a foundation to institute local, regional and national groundwater management plans. However, databases will only be useful if all drillers share borehole data as required by law (see point $3 b$ ).

6. Prevent cross-contamination of aquifers caused by leaking borehole seals, by ensuring the proper design and construction of wells. The problems generated by faulty borehole seals are much greater than the small effort required to prevent them. A faulty seal is difficult to detect and remediating the consequent contamination is expensive, often beyond the means of local well-owners or even municipalities. Frequently, costly water treatment procedures are employed to decontaminate drinking water, whilst a properly drilled borehole would have prevented the problem [5].

7. Develop better scientific methods and institute higher standards when measuring the vulnerability of aquifers which take into account not only a complete inventory of boreholes in a given region, but also their integrity. Regulations must be instituted that make it mandatory for engineers, geoscientists and other professionals to take into account the cumulative effects of multiple boreholes when preparing aquifer vulnerability reports for municipalities or governments.

8. Control the quantity and location of boreholes drilled in remote areas. This is urgent. Before groundwater is jeopardized in wilderness areas on a very large scale, governments and environmental associations need to act. Much political will and decision-making will be needed to prevent the contamination of groundwater in the remaining pristine wilderness areas of the planet.

Uncontrolled drilling is incompatible with sustainable water management. To protect the planet's renewable supply of clean water, we may be obliged to control and manage the holes that we drill into the earth. This implies a responsibility on the part of all political and social groups, from the individual resident all the way to legislative bodies. Many concrete actions can be realistically implemented in the immediate future, such as improving drilling practices, registering boreholes and instituting well-pooling, to help ensure a genuine long-term ground- water sustainability.

\section{Acknowledgements}

The author acknowledges the financial support of the National Sciences and Engineering Research Council of Canada (NSERC individual research grant). Grateful thanks are expressed to Ms Josée Kaufmann for editorial collaboration. Thanks are also extended to Dr. John W. Molson and Dr. Gilles Wendling for their valuable comments, which greatly improved the original manuscript.

\section{REFERENCES}

[1] S. Lacombe, E. Studicky, S. Frape and A. Unger, "Influence of Leaky Boreholes on Cross-Formational Ground Water Flow and Contaminant Transport," Water Resources Research, Vol. 31, No. 8, 1995, pp. 1871-1882. doi:10.1029/95WR00661

[2] S. N. Sterling, B. L. Parker, J. A. Cherry, J. H. Williams, J. W. Lane Jr. and F. P. Haeni, "Vertical Cross Contamination of Trichloroethylene in a Borehole in Fractured Sandstone," Ground Water, Vol. 43, No. 4, 2005, pp. 557-573. doi:10.1111/j.1745-6584.2005.0087.x

[3] M. Bonte, P. J. Stuyfzand, A. Hulsmann and P. Van Beelen, "Underground Thermal Energy Storage: Environmental Risks and Policy Developments in the Netherlands and European Union,” Ecology \& Society, Vol. 16, No. 1, 2011, Article ID: 22.2011.

[4] J. Jiménez-Martínez, R. Aravena and L. Candela, “The Role of Leaky Boreholes in the Contamination of a Regional Confined Aquifer. A Case Study: The Campo De Cartagena Region, Spain,” Water Air Soil Pollution, Vol. 215, 2011, pp. 311-327. doi:10.1007/s11270-010-0480-3

[5] B. L. Morris, A. R. L. Lawrence, P. J. C. Chilton, B. Adams, R. C. Calow and B. A. Klinck, "Groundwater and Its Susceptibility to Degradation: A Global Assessment of the Problem and Options for Management,” Early Warning and Assessment Report Series, RS. 03-3, United Nations Environment Programme, Nairobi, 2003.

[6] P. M. Santi, J. E. McCray and J. L. Martens, "Investigating Cross-Contamination of Aquifers," Hydrogeology Journal, Vol. 14, 2006, pp. 51-68. doi:10.1007/s10040-004-0403-8

[7] M. K. Landon, B. C. Jurgens, B. G. Katz, S. M. Eberts, K. R. Burow and C. A. Crandall, "Depth-Dependent Sampling to Identify Short-Circuit Pathways to Public-Supply Wells in Multiple Aquifer Settings in the United States," Hydrogeology Journal, Vol. 18, 2010, pp. 51-68. doi:10.1007/s10040-009-0531-2

[8] R. Chesnaux, "Sealing Pumping Wells and Protecting Groundwater Resources-Detecting and Characterizing Defective Well Seal to Prevent Hydraulic Short-Circuits between Aquifers [in French]," Presses Universitaires Européennes, 2010.

[9] D. Meiri, "A Tracer Test for Detecting Cross-Contamination along a Monitoring Well Column,” Ground Water Monitoring Review, Vol. 9, No. 2, 1989, pp. 78-81. 
doi:10.1111/j.1745-6592.1989.tb01142.x

[10] R. Chesnaux, R. P. Chapuis and J. W. Molson, “A New Method to Characterize Hydraulic Short-Circuits in Defective Borehole Seals,” Ground Water, Vol. 44, No. 5, 2006, pp. 676-681.

[11] R. Chesnaux and R. P. Chapuis, "Detecting and Quantifying Leakage through Defective Borehole Seals: A New Methodology and Laboratory Verification,” Geotechnical Testing Journal, Vol. 30, No. 1, 2007, pp. 17-24.

[12] M. Zhang and S. Bachu, "Review of Integrity of Existing Wells in Relation to $\mathrm{CO}_{2}$ Geological Storage: What Do We Know?” International Journal of Greenhouse Gas Control, Vol. 5, 2011, pp. 826-840. doi:10.1016/j.ijggc.2010.11.006

[13] Walkerton Inquiry, "Report of the Walkerton Inquiry, Part 1: The Events of May 2000 and Related Issues,”
2002. http://www.walkertoninquiry.com

[14] J. Livernois, “The Economic Costs of the Walkerton Water Crisis,” In: The Walkerton Inquiry, Commissioned Paper 14, 2001.

[15] L. Aller, T. Bennett, J. H. Lehr, R. J. Petty and G. Hackett, "DRASTIC: A Standardized System for Evaluating Groundwater Pollution Potential Using Hydrogeologic Setting," US Environmental Protection Agency Rep EPA/600/287/035, 1987.

[16] R. Chesnaux, M. Lambert, U. Fillastre, J. Walter, M. Hay, A. Rouleau, R. Daigneault, D. Germaneau and A. Moisan, "Building a Geodatabase for Mapping Hydrogeological Features and 3D Modeling of Groundwater Systems: Application to the Saguenay-Lac-St-Jean Region, Canada," Computers \& Geosciences, Vol. 37, 2011, pp. 1870-1882. doi:10.1016/j.cageo.2011.04.013 